\title{
Building Brand Equity through Advertising
}

\author{
Africa Makasi
}

PhD student, University of KwaZulu-Natal, South Africa and Harare Institute of Technology, Zimbabwe

africa.makasi@yahoo.com

Krishna Govender

University of KwaZulu-Natal, South Africa and Regenesys Business School, South Africa

Cephas Rukweza

Women's University in Africa, Zimbabwe (MBA student).Africa Makasi. Harare Institute of Technology. Department of Technopreneurship, Zimbabwe. P.O. Box B.E 277.Belvedere, Harare, Zimbabwe.

Email: africa.makasi@yahoo.com

\section{Doi:10.5901/mjss.2014.v5n20p2613}

\section{Abstract}

The study examined the impact of advertising on building brand equity in Zimbabwe's Tobacco Auction floors. In this study, 100 farmers were selected from 88244 farmers registered in the four tobacco growing regions of country. A structured questionnaire was used as a tool to collect primary data. A pilot survey with 20 participants was initially conducted to test the reliability of the questionnaire. Results of the pilot study were analysed to test for reliability using SPSS.Results of the study found that advertising affects brand awareness, brand loyalty, brand association and perceived quality. 55\% of the respondents agreed that advertising changed their perceived quality on auction floors. A linear regression analysis was performed to predict brand quality as a function of the type of farmer, source of information, competitive average pricing, loyalty, input assistance, service delivery, number of floors, advert mode, customer service, floor reputation and attitude. There was a strong relationship between brand quality and the independent variables as depicted by the regression coefficient of 0.885 and the model fit is perfect at $78.3 \%$. From the ANOVA tables, a good fit was established between advertising and brand equity with $p=0.001$ which is less than the significance level of 0.05 . While previous researches concentrated on the elements of brand equity as suggested by Keller's brand equity model, this research has managed to extend the body of knowledge on brand equity by exploring the role of advertising. Future research should assess the relationship between advertising and a brand association.

Keywords: brand equity, advertising, brand association, competitiveness.

\section{Introduction}

While previous researchers have focused primarily on defining and measuring the concept of brand equity and, to a lesser extent, understanding its causes and effects, there is a broad-based agreement that one of the major contributors to brand equity is advertising (Aaker \& Biel 1993) and must be studied. Building a reputable brand has been the major driver for success in the competitive market place. Developing strong brands has been used as an effective defensive mechanism against competition by many business organizations. For organizations to grow and develop successful brands, the importance of advertising to enhance brand equity cannot be over emphasized. The Tobacco Auction Floors in Zimbabwe have not been proactively employing advertising in order to build brand equity and the implications are that there is need for directors running these companies to take a more positive and proactive stance to effectively blend advertising variables in order to develop hybrid advertising mix strategies. Despite the presence of well documented evidence and research on advertising's influence on consumer awareness, limited research has been done to establish the impact of this marketing communications mix variable on building brand equity.

\section{Literature Review}

Patrick, Maggie\& Van den (2010) define advertising is a sponsored activity by a number of stakeholders primarily with the aim of inducing awareness, persuading (building brand liking and encouraging brand switching) and reminding target 
markets that the brand is on the market. Advertising is usually paid by an identified sponsor with the aim to influence the people's attitudes towards certain people, organizations, products, services or ideas (Belch \& Belch 2003).Advertising was born because of the marked rise in mass production in the late 19th and 20th centuries, although it had existed earlier than that period in ancient Egypt where sales messages and wall posters were predominant promotional media and marketers of that medieval period (Patricia \& Adam 2007). Since then advertising proliferated over the decades and has grown to be the dominant marketing communication mix element for both profit and non-profit making oriented enterprises world over (Patricia, \& Adam 2007). Kotler and Armstrong (2008) describe advertising as an approach to "non-personal communication which is paid for". Advertising is usually paid by an identified sponsor with the aim to influence the people`s attitudes towards certain people, organizations, products, services or ideas (Belch \& Belch 2003).

Advertising plays an important role in today's competitive world by which organizations communicate with their customers, both current and potential. Companies allocate a considerable part of their sources to advertising (O'Quinn, Allen \& Semenik 2009). To help check whether or not advertising budgets are earning the best return on investment, it is important to know how effectively advertisement capture and maintain audience attention and engage viewers( De Ros 2008). One of the most difficult problems faced by advertising agencies, and advertisers, remains the issue of measuring the effectiveness of the advertising they create and run (Hall 2001).Advertising effectiveness is in two forms, that is sales effectiveness and communication effectiveness (Tsai and Tsai 2006). Sales volume is used to measure sales effectiveness as a gauge, and the level that a message is noticed, understood, accepted and is changing attitude and behaviour for measuring communication effectiveness (Tsai and Tsai 2006). Advertisement recognition is the recall memory of audience, after watching target advertisements, about advertisement content. Advertisement Attitude are constant likes and dislikes, feelings of audience towards advertisements after watching target advertisements, which also means the whole opinion of examiners after watching advertisements (Tsai \& Tsai 2006). All advertising campaigns aim to achieve a specific objective. The specific objectives of an advertising campaign may adopt many forms such as create awareness of a new product or brand, inform consumers of the benefits of the product or brand, create the desire perceptions of the product or brand, create a preference for the product or brand, persuade customers to purchase the product or brand (Bendixen 1993).

Kotler (1988) sees advertising as one of the four major tools companies use to direct persuasive communications to target buyers and public noting, "It consists of non-personal forms of communication conducted through paid media under clear sponsorship". According to Kotler (1988), the purpose of advertising is to enhance potential buyers' responses to the organization and its offering, emphasizing, "It seeks to do this providing information, by channelling desire, and by supplying reasons for preferring a particular organization's offer." Customers are valuable assets for the enterprise, but they can be costly to acquire and retain (Kotler 1988). The customers' difference in the course of their relationship with the enterprise reflects in their contributions to the enterprise value throughout their tenure. To the extent that different acquisition strategies bring different "qualities" of customers, the acquisition effort has an important influence on the long-term profitability of the enterprise (Kotler 1988). Both practitioners and scholars have emphasized that enterprises should spend not to acquire just any customer but rather the "right" kind of customer (Blattberg \& Deighton 1996; Blattberg, Getz, \& Thomas 2001; Hansotia \& Wang 1997; Reichheld 1993), because advertising plays a very important role in this field. Advertisers pay a particular attention to the customer in order to attract and retain him/her. According to Kotler (2003) and Jokubauskas (2003), both the businesses and individual sellers should ask themselves what should the advertising of their products, services are, and what impact should it make on the customer. Advertising provides the alternatives for example through magazines, press ads, radio and television together with opinions of relatives and friends. After evaluating the alternatives, the consumer then makes the purchase (Kotler \& Armstrong 2008).

Consumers are more likely to buy a product if they can remember an advert. However, recalling an advert does not necessarily lead to buying the brand advertised (Kotler \& Armstrong 2008). The type of television program in which the brand can also affect consumer's feelings about the ad and the brand it promotes. Viewers judge adverts placed in happy programs as more effective and recall them somewhat better (Dibb 1993)

\subsection{Success of Advertising campaign}

The success of any advertising campaign hinges on the use of market research and also depends on the advertiser's knowledge of the social and temporal context in which the adverts are viewed (Jefkins \& Yadin 2000). There are a number of factors that influence advertising effectiveness such as brand name prominence, brand image, advertising recall, persuasion, search for information, buying intention and the purchase decision process (Jefkins \& Yadin 2000). In his paper, Holistius (1990) examines a mathematical correlation between the two forces and demonstrates how they 
interact with external forces. The results of the study showed that increases in advertising boosted sales and whenever there was a peak in advertising, there was a corresponding peak in sales volume. Jones (1994), a professor at Syracuse University in the USA writing in Adman, observes regarding the short and long term impacts of advertising. 50\% of advertising campaigns have a noticeable sales effect in both the short term and long term (Jones 1994). The underlying problem of measuring the effects of advertising is that virtually all of the methods available for measuring and attributing sales variations to advertising are only possible in the short term. Against this, Fletcher (1992) argues that no advertiser waits for a year for their advertising to take effect. Advertising must work both quickly and residually and must generate a response both today and tomorrow. Unless short-term results achieved, the long-term benefits will never materialize. Advertising could not possibly work in the future if it does not work in the present (Fletcher 1992).

\subsubsection{Print advertising}

Patricia \& Adam (2007) outline a list of print media forms, which include "mass-market magazines, newspapers, the yellow pages, inserted media, outdoor posters and transit advertising, signage and point of sales materials, direct mail, custom magazines, sales collateral, and catalogues". Normally, advertising products and services through newspapers or magazines has been a common practice. Apart from these two, print media also provide options such as brochures, leaflets and fliers, which are used on appropriate situations for advertising purposes. (Patricia \& Adam 2007) Mostly, newspapers and magazine media charge their advertising space based on the size of the advertisement, the position of the advertisement in the newspaper, such as front page, middle page or the last page and the readership of the publications. According to Fill (2006), printed message affords advertisers the opportunity to give detail to their message as opposed to other media such as television, radio and billboards. Such added details can be in the form of pictures or photographs, or an illustration on how a market offering is used (Fill, 2006). Due to their years of existence on the market, magazines and newspapers have become credible sources for information compared to the newly introduced online media where anything can be published (Brookins, 2012). Therefore, print advertising has to be able to reach the kinds of potential customers targeted through specified media. No matter how complex the product or service maybe one can still meet the intended readers by planning print advertising properly (Griffiths, 2004).

\subsubsection{Outdoor advertising}

Outdoor advertising consists of not only media such as billboards, posters, kiosks but also transit media in the form of messages on automobiles (Patrick 2010). Consequently, it has an effective reach and very high frequency. Its message lifetime is durable and can be seen repeatedly (Patrick 2010). Billboard advertising is very common and popularly used in town periphery, which makes it effective. By virtue of their reach and frequency, tobacco auction floors can take advantage of these attributes to enhance highly esteemed brands for their companies. However, the tobacco auction floors may need to design billboards that are attractive in order to appeal to a large pool of potential customers.

\subsubsection{Event sponsorship}

Event sponsorship offers an excellent platform for sponsoring organizations to promote products, services and ideas (Fill 2006). The company can organize trade fairs, or even exhibitions for advertising their products and services. As for tobacco auction floors they can display their programs at business expositions, trade fairs and any other events. This will assist them to create awareness, develop perceived brand equity, loyalty and brand associations for their floors to different stakeholders. Geoff \& Lester (2011) noted that most exhibitions are based on industry sector lines such as the Agricultural shows. Mostly, these shows are for specific categories of goods and services. Despite technological advancements in the business world, trade shows have remained a primary means for creating sales and generating leads for many businesses, so tobacco auction floors take advantage of trade shows to build brand equity (Fill 2006).

\subsubsection{Broadcast advertising}

Broadcast advertising has proved overtime to be the best among all advertising forms. Radio advertising specifically important in the following regards namely cheapness, penetration, transmission times, human voice and that it does not enforce serious attention (Jefkins \& Yadin 2000). Thus, radio advertising is cost effective as it appeals to the mass market which results in cost economies. The ability to reach multitudes of targeted audience makes this broadcast method economic and above all its application of the human voice has given its advantage over other passive and static media 
for advertising which include print, outdoor and other forms of direct mail advertising. O' Guinn, Allen \& Semenik (2009) argue that radio advertising has the greatest reach and frequency as it can reach customers in their homes, vehicles and offices. Jefkins \& Yadin (2000) claim that television advertising is an "imp active medium" which delivers the advertisement right into the home of the potential buyer of the product including other immediate family members who can influence the purchase decision of the buyer. According to Jefkins \& Yadin (2000), television advertising has outlived other forms of advertising because of its ability to create "realism" via its use of colour, sound and action (Patrick 2005) noted that broadcast sponsorship is most relevant to advertising corporate brands since it is able to achieve the awareness and image building objectives of the sponsoring firm.

\subsubsection{Mobile Marketing}

Although it is beyond of this article to provide an exhaustive review and analysis of mobile marketing literature, a short commentary should be made on divergent conceptualizations and development of mobile marketing. Leppäniemi et al. (2006), in their detailed review of mobile marketing research, observed that marketing communications in mobile media has, implicitly or explicitly, been conceptualized as (1) mobile marketing, (2) mobile advertising, (3) wireless marketing, and (4) wireless advertising. Overall, their literature review yielded 21 distinct definitions or meanings of marketing communications in mobile media. In addition, Leppäniemi et al (2006) noted that most of the definitions are deeply embedded in technology, and therefore there is a tendency to mistake the technologies for the concept itself. In fact, it seems that the same conceptual disagreement appears to be involved in all mobile commerce related discussions. For instance, Balasubramanian et al. (2002, p. 349) noted that "...no formal conceptualization of m-commerce currently exists. Conceptual agreement is necessary to promote a shared understanding of m-commerce, one that encourages clarity of communication and convergence in thinking."

There is, however, a growing consensus as to the most appropriate way in which mobile marketing should be defined. In a recent commentary, Mobile Marketing Association (2006, p. 22) defined mobile marketing as "the use of wireless media as an integrated content delivery and direct-response vehicle within a cross-media marketing communications program." We adopt their definition in this article and highlight its emphasis on two-way communications and integration of mobile media into a cross-media marketing communications program.

\subsection{Advertising on Brand equity dimensions}

Advertising is a successful factor to provide brand equity, particularly where the sales promotion is failing to increase sales (Boulding, Lee \& Staelin, 1994; Chay \& Tellis, 1991; Johnson, 1984; Lindsay 1989; Maxwell, (989; Simon and Sullivan 1993) identified the positive effect of advertising. Cobb-Walgren (1995) found that spending advertising costs has positive effect on brand equity and its dimensions. Advertising is an external signal to show the quality of products (Milgrom \& Roberts 1986). Heavy investing in advertising indicates that company invested on its brand which is evolved high quality (Kirmani \& Wright 1989). Moreover, Archibald et al (1983) found that not only advertising just shows high quality, but also make well profit. In addition, Aaker and Jacobson (1994) identified a positive relationship between advertising and perceived quality. Thus, we could say that advertising positively effects on perceived quality and subsequently brand equity. Advertising play an important role in increasing brand awareness. Repetitive advertising program increase the chance of paying attention to brand, simplify costumers' selection and habituate the selection of brand (Hauser \& Wernerfeldt 1990). Hence, advertising is positively concerned with the awareness of the brand association which is increased brand equity. Moreover, advertising attempts are positively concerned with brand loyalty because it is reinforced the brand awareness and steer the viewpoints to the brand (Shimp 1997).

\subsection{Influence of advertising on brand equity}

In a study conducted by Cobb-Walgren (1995) they found that advertising can influence brand equity a number of ways. With advertising, it is able to create awareness of the brand and increase the probability that the brand is included in the consumer's evoked set. It can contribute to brand associations which, when stored in accessible memory, translate into "non-conscious but reliable behavioural predisposition" Krishnan \& Chakravarti (1993). Advertising can affect the perceived quality of a brand, and it can influence usage experience (Cobb-Walgren 1995). Nelson (1974) demonstrated that heavy advertising can improve perceived quality for experience goods, which by definition are difficult to evaluate prior to purchase. Advertising can make positive brand evaluations and attitudes readily accessible in memory CobbWalgren (1995). This is crucial to the development of brand equity, where Herr and Fazio (1992) found in their study that 
favourable brand attitudes will shape the perceptions and behaviour of a consumer if those attitudes can be instantly enhance. These perceptions, in turn, contribute to the meaning or value that the brand adds to the consumer that is, brand equity (Cobb-Walgren 1995). Brand equity will then influence consumer preferences and purchase intentions, and ultimately brand choice (Cobb-Walgren 1995).

It is quite common to regard advertising as a major factor in leveraging brand equity (Achenbaum 1989; Lindsay 1990). It is worth noting that customers are not passive recipients of image-laden advertising. Joyce (1991) suggests that people took away from communications, including advertising, what they chose to, and actually brought existing preconceptions to them. In reality, brand values are subjective, a point stressed by McDonald (1992) who suggests that it is consumers and their habit-forming tendencies that create branding; International Journal of Marketing Studies Vol. 2, No. 1 branding is inseparable from the ability to choose. What advertising does is to help control the acquisition of value, and give it direction. Advertising can influence brand equity a number of ways. It can create awareness of the brand and increase the probability that the brand is included in the customer's evoked set. It can contribute to brand associations which, when stored in accessible memory, translate into non-conscious but reliable behavioural predispositions (Krishnan \& Chakravarti 1993). Advertising can affect the perceived quality of a brand, and it can influence usage experience. No published studies to date have examined all of the components of brand equity as they relate to advertising. Johnson (1984) looked at the relationship between advertising spending and brand loyalty. For those brands that suffered a decline in brand loyalty over time, one of the major contributing factors was a lack of advertising support. Therefore it is very important for company's brand to develop a well-communicated strategy that would help them gain a better brand's position and protecting them from other rivals or competitors (Johnson 1984).

\subsection{Brand Equity Concept}

There are a lot of definitions for brand equity, but the researcher picked some significant definition which is derived from several authors, Brand equity is a set of assets and commitments linked to a brand's name and symbol that adds to (or subtracts from) the value provided by a product or service to a firm and/or that firm's customers (Aaker 1991: 1996). Brand equity is the differential effect of brand recognition on consumer response to the marketing of that brand Keller (1993). Brand equity is a power that a brand may have achieved it in a market because of its name, sign and logo (Farquhar 1989). The concept of brand equity as discussed repeatedly in various sources of literature and there is no consensus on the definition due to the difficulty practitioners and marketers encounter in measuring equity. Apparently, there seems to be two approaches to defining brand equity namely the financial and consumer perspective. Simon and Sullivan (1991) note that brand equity defined as the value of the brand to the firm. Aaker (1991) \& Keller (2008) concur on the contention that brand equity denotes the value endowed to the brand by the consumer. One of the many interesting questions facing today's brand managers concerns how to develop a better understanding of the appropriate relationship between constructs such as brand equity and customer loyalty (Taylor 2004). By having a strong brand, companies not only could facilitate the differentiation of their offer from the competitors, with branding. The added value that a brand name gives to a product is now commonly referred to as brand equity (Aaker 1991). Brand name adds value to each of these interested parties which include the investors, manufacturers, and the retailers. Brand equity provides a strong platform for introducing new products and insulates the brand against competitive attacks. From the perspective of the trade, brand equity contributes to the overall image of the retail outlet. It builds store traffic, ensures consistent volume, and reduces risk in allocating shelf space (Cobb-Walgren 1995). However, if the brand has no meaning to the consumer, automatically there wouldn't be of any value to the investors, the manufacturer, and the retailer unless there is value to consumer Farquhar (1989); Crimmins (1992) to or subtract value from a product or service, coined a more detailed definition.

Brand equity is the value of the brand in the marketplace (Keller 2008). However, what this means exactly is often not fully or clearly understood. High brand value, a brand with high equity, means that the brand has the ability to create some sort of positive differential response in the marketplace. This can mean that your brand is easily recognizable in advertising or seen on a yard sign. It could mean that when someone asks for a referral, your brand is the first brand recommended to others. All of these are positive responses to the brand - a readily recognizable brand, a brand remembered quickly and easily when needed, one that individuals are willing to pay a premium price to acquire, and a brand recommended to others (Keller 2008). These associations created in everything done - advertising messages, logos, names used, segments served, etc. If you use a statement in your advertising that you are the "Team to Trust" you hope that "trust "will become a brand association. If you serve a specific segment, then that segment is likely to become associated with your brand. Basic branding elements are brand name, slogans, logo, symbols/pictures, and markets served (Aaker 1996). 
Branding elements are the most noticeable features associated with the brand itself - the brand name, slogans, logo, and symbols or pictures used on product offerings and contained in any marketing messages. However, it is important to know that branding elements extend to the content of the marketing message itself and even you are positioning within the marketplace Aaker $(1991,1996)$. Every aspect of these elements creates your brand image. It is important that this image is relevant to your customer, clear in what it stands for, and offers some point of differentiation from your competition. Brand equity regarded as a mix that includes both financial assets and associations. Actually, brand equity is the value added to the product Keller (1993), or the perceived value of the product in consumers' minds Kimetal, (2008). Brand equity is an important concept in brand management for both theoretical and practical reasons. From a theoretical perspective, it is relevant to understand what key elements make up brand equity (Punj \&Hillyer 2004).

One important consensus among the definitions is that brand equity is the incremental value of a product due to the brand name (Srivastava and Shocker 1991). Collectively, brand equity consists of four dimensions: brand loyalty, brand awareness, perceived quality of brand, and brand associations, as proposed by Aaker $(1991,1996)$ and Keller (1993). Ultimately, brand equity equals consumer brand knowledge. You create your brand's equity as you create your market's consumer knowledge. Recall that brand equity is the value of the brand in the marketplace. Brand equity is an asset that would receive returns on today, tomorrow, and the days to come (Keller 1993). As with any asset, you have to decide how best to invest in it. Invest wisely and you will have the type of brand equity that provides good returns. Build a brand that is high in awareness Keller (1993). Awareness is a key determinant identified in almost all brand equity models (Aaker (1991; Kapferer 1991; Keller 1992; Agarwal \& Rao 1996; Krishnan 1996; Na, Marshall \& Keller 1999; Aaker; 1991) defines brand awareness as the capability of consumers to recognize and recall the brand in clutter .Brand awareness is critical in the building of brand equity in the sense that it precedes all other variables (Aaker 1991 and Kapferer 1991). Consumers should be aware of a brand in order to develop a set of positive brand associations and attained through aggressive marketing communications. Awareness may lead to consumers developing positive perceptions of the brand, which usually results in loyalty (Oliver 1999). Keller (2003) defines awareness as "the customers' ability to recall and recognize the brand as reflected by their ability to identify the brand under different conditions and to link the brand name, logo, symbol, and so forth to certain associations in memory". Brand awareness includes consumer recognition, recall, top-of-mind awareness, knowledge dominance, and recalls performance of brands, as well as brand attitude (Kim 2008). Aaker (1996) identifies other higher levels of awareness besides recognition and recall Aaker (1991). He includes top-ofmind, brand dominance, brand knowledge and brand opinion. Brand knowledge is the full set of brand associations linked to the brand Keller (1993).According to Aaker (1996), for new or niche brands, recognition can be important. For wellknown brands, recall and top-of-mind are more sensitive and meaningful. Brand knowledge and brand opinion are used to enhance the measurement of brand recall.

\subsubsection{Brand loyalty}

According to Oliver (1999), brand loyalty is a deeply held commitment to rebuy a preferred product/service consistently in future thereby causing repetitive same brand purchasing, despite situational influences and marketing efforts having the potential to cause switching behaviour. Aaker (1991) defines brand loyalty as the attachment that a customer has to a brand. In marketing situations, brand loyalty determines consumer choice of brands and consumers may be insensitive to price increases or decreases (Keller 2003). Brand loyalty considered as one of the most important factors affecting consumer choice (Baldinger \& Rubinson 1996). Loyalty is a core dimension of brand equity. Grembler and Brown (1996) describe different levels of loyalty. Behavioural loyalty is linked to consumer behaviour in the marketplace that can be indicated by number of repeated purchases Keller (1998) or commitment to rebuy the brand as a primary choice (Oliver 1997, 1999). Cognitive loyalty which means that a brand comes up first in a consumers' mind, when the need to make a purchase decision arises, that is the consumers' first choice. The cognitive loyalty closely linked to the highest level of awareness (top-of-mind), where the matter of interest also is the brand, in a given category, which the consumers recall first. Thus, a brand should be able to become the respondents' first choices (cognitive loyalty) and is therefore purchased repeatedly (behavioural loyalty) Keller (1998). Chaudhuri \& Holbrook (2001) mention that brand loyalty related to brand price. Aaker (1996) identify price premium as the basic indicator of loyalty. Price premium defined as the amount a customer will pay for the brand in comparison with another brand offering similar benefits and it may be high or low and positive or negative depending on the two brands involved in the comparison (Aaker 1996).

\subsubsection{Perceived quality}

Zeithaml (1988) defines perceived quality as a "product's overall excellence or superiority". In this instance, quality 
considered as a customer based brand equity variable, which integrates perceptions and experiences of a consumer. It connotes that quality is a customer perspective issue since the customer judges the performance of the products according to their expectations and the performance of other products in the market Zeithaml (1998). Therefore it is based on consumers' or users' subjective evaluations of product quality . The most common definition of perceived quality integrates consumer experience of the service and perceptions of the firm providing the service (Gonza'lez, Comesan a, \&Brea, 2007). Perceived quality considered a core customer based brand equity factor because it has been associated with the willingness to pay a price premium, brand purchase intent, and brand choice. Perceived quality is viewed as a dimension of brand equity Aaker (1991); Kapferer (1991); Kamakura and Russell (1991); Martin \& Brown (1991); Feldwick (1996) rather than as a part of the overall brand association Keller (1992), Gordon, di Benedetto \& Calantone (1994). Perceived quality is the customer's judgment about a product's overall excellence or superiority that is different from objective quality (Zeithaml 1988). Objective quality refers to the technical, measurable and verifiable nature of products/services, processes and quality controls. High objective quality does not necessarily contribute to brand equity (Anselmsson 2007). Since it is impossible for consumers to make complete and correct judgments of the objective quality, they use quality attributes that they associate with quality Olson and Jacoby (1972), Zeithaml (1988), Ophuis \& Van Trijp (1995), Richardson (1994); Acebro'n \& Dopico (2000). Perceived quality formed to judge the overall quality of a product/service. Boulding and other researchers (1993) argued that quality directly influenced by perceptions. Consumers use the quality attributes to compare quality of an unfamiliar product. It is therefore important to understand the relevant quality attributes with regard to brand equity. Zeithaml (1988), Steenkamp (1997) classify the concept of perceived quality in two groups of factors that are intrinsic attributes and extrinsic attributes. The intrinsic attributes are related to the physical aspects of a product (e.g. colour, flavour, form and appearance); on the other hand, extrinsic attributes are related to the product, but not in the physical part of this one (e.g. brand name, stamp of quality, price, store, packaging and production information Bernue (2003). It is difficult to generalize attributes, as they are specific to product categories (Olson \& Jacoby 1972)

\subsubsection{Brand associations}

Brand associations are defined as anything linked in memory to a brand and brand image as a set of associations, usually in some meaningful way (Pitta\& Katsanis 1995). Brand associations involves attributes, benefits, and attitudes can be stored in consumers 'minds after brand awareness is in their memory (Keller 1993).Brand associations are one of the most significant constituent parts of brand equity Aaker (1991), Yoo \& Donthu (1997). A brand association conceptualized to denote anything that has memory links to the brand. These links grow and develop as a consumer repeatedly exposed to the brand. Keller (2008) expresses that brands endowed with several positive brand associations have positive customer based brand equity. Brand associations are fundamentally essential in positioning and differentiating brands. They rekindle the interest of consumers to purchase a brand and create a positive attitude towards a brand. Brand associations are central to brand equity. In conceptualizing brand equity, Keller (1993) depicts attitudes as the most abstract and highest level of brand association. Everything you do in terms of marketing and actions creates brand associations (Pitta \& Katsanis 1995). A brand association is the most accepted aspect of brand equity (Aaker 1992). Associations represent the basis for purchase decision and for brand loyalty (Aaker 1991). Brand associations consist of all brand-related thoughts, feelings, perceptions, images, experiences, beliefs, attitudes Kotler (1988) \& Keller (2008) and are anything linked in memory to a brand. Other researchers Farquhar \& Herr (1993), Chen (1996), Brown \& Dacin (1997), Biel (1992) identify different types of association that contribute to the brand equity. Chen (2001) categorized two types of brand associations - product associations and organizational associations.

\subsubsection{Product Associations}

Product associations include functional attribute associations and non-functional associations Chen (2001). Functional attributes are the tangible features of a product Keller (1993), Hankinson \& Cowking (1993), de Chernatony \& McWilliams (1989). While evaluating a brand, consumers link the performance of the functional attributes to the brand (Pitta \& Katsanis, 1995; Lassar, 1995). If a brand does not perform the functions for which designed, the brand will has low level of brand equity. Performance defined as a consumer's judgment about a brand's fault-free and long-lasting physical operation and flawlessness in the product's physical construction (Lassar 1995). Non-functional attributes include symbolic attributes Aaker (1991), Keller (1993), Farquhar \& Herr( 1993), Chen (1996), Park (1986) which are the intangible attributes that meet customer' needs for social approval, personal expression or self-esteem Keller (1993), Hankinson \& Cowking (1993), de Chernatony \& McWilliams (1989), Pitta \& Katsanis (1995). Customers linked social 
image of a brand, trustworthiness, perceived value, differentiation and country of origin to a brand. Organizational associations include corporate ability associations, which are those associations related to the company's expertise in producing and delivering its outputs and corporate social responsibility associations, which include organization's activities with respect to its perceived societal obligations (Chen 2001).According to Aaker (1996), consumers consider the organization that is the people, values, and programs that lies behind the brand. Brand-as-organization can be particularly helpful when brands are similar with respect to attributes, when the organization is visible (as in a durable goods or service business), or when a corporate brand is involved.

\subsection{Brand Equity in a Competitive Market}

According to Prentice (1991) and Ryan (1991) the consumer's perception of brand value comes from many sources, but essentially it is based on ideas - rational or emotional - that set the brand apart from competitive brands. Farquhar (1989) also suggests that advertising can make positive brand evaluations and attitudes readily accessible in memory and it is crucial to the development of brand equity. This idea is supported by Herr and Fazio (1992), where they found that favourable brand attitudes will only guide perceptions and behaviour if those attitudes can be instantly evoked. Many authors have presented several measures of brand equity, for example, (Farquhar \& ljiri 1991; Kamakura \&Russess, 1993; Kapferer \& Laurent 1988; Park \& Srinivasan 1994; Simon \& Sullivan (993), after reviewing the above articles we conclude that the premium prices enjoyed by many brands have often been identified with brand equity( Aaker 1991 and Farquhar 1989). Holden (1992) maintains that brand equity arises from greater brand choice probability by consumers and is reflected in willingness to pay premium prices. Other behavioural/choice variables that might indicate brand equity are likelihood of purchase (Smith \& Swinyard 1983) and purchase intentions (Machleit, Madden, \& Allen 1990). Similar dimensions were also identified by other researchers, whereby Shocker and Weitz (1988) propose brand loyalty and brand associations as the dimension for brand equity. Keller (1993) suggests brand knowledge, comprising brand awareness and brand image as a component of brand equity. Taking into considerations of the suggestions mentioned above. Taylor (2004) indicates that brand equity is unique from customer loyalty .Brands do possess negative customerbased brand equity, through customers' expression when consumers react less favourably to the marketing activities associated with a brand (Keller, 1988; Taylor, 2004). In Keller's view, one of the characteristics of brands possessing strong brand equity is stronger brand loyalty. This view correspond with that of Aaker (1991) who argued that brand loyalty could be considered both as a dimension and an outcome of brand equity and competitiveness.

\section{Methodology}

Stratified probability sampling was used in this research. Tobacco farmers were stratified into four tobacco grown provinces. This was necessitated by the geographical displacement of tobacco farmers. Stratified sampling was chosen because it gave all segments under consideration an equal chance of representation in proportion to their sizes. A sample size of one-hundred farmers was scientifically drawn from active tobacco farmers using systemic random probability sampling technique where 1 in every 884 farmers was selected from a population size of eighty eight thousand two hundred and forty four (88 244).

Structured questionnaires were used as the major tool to collect primary data. The questionnaire was selfadministered and a data requirements table created to ensure that essential data was collected. Supplementary material was obtained through semi-structured face to face interviews. To ensure the validity of the findings from the study, the researcher engaged in a pilot study to test the questionnaires. The researcher also made sure that the questionnaires and field interviews in this study were done correctly to ensure the reliability and validity of the findings through personal involvement in the distribution and collection of the questionnaires and avoiding intermediaries who could damage or disturb the data collection and interpretation processes. Data was collected primarily through interviews and surveys. Data analysis started tentatively in the field, then final analysis was done after the collection of all data. A quantitative approach was used to analyse data through the use of Statistical Package for Social Sciences (SPSS) software.

\section{Results}

Figure 1 below shows responses to the statements related to auction floor advertisement. $43 \%$ of the respondents agreed that they were aware that auction floors do advertise. $29 \%$ of the respondents strongly agreed that auction floors advertise. About $5 \%$ of the interviewees strongly disagreed and were not aware that auction floors do advertise themselves. Nearly $5 \%$ of the respondents were reserved and remained neutral about their opinion on auction floors 
advertising themselves.

$44 \%$ of the respondents agreed that advertising influenced their loyalty to auction floors. About $1 \%$ of the respondents was neutral and did not want to respond to the fact that advertising influenced their loyalty to any auction floor. $29 \%$ of the respondents strongly agreed that advertising influenced their loyalty. $2 \%$ of the interviewees strongly disagreed advertising influenced their loyalty to auction floors. About $18 \%$ of the famers interviewed disagreed to the notion that advertising their loyalty to auction floors. Less than $1 \%$ of the respondents was neutral and had a reserved opinion about their response to the influence of advertising on loyalty.

$55 \%$ of the respondents agreed that advertising changed their perceived quality on auction floors. The percentage of respondents who strongly agreed that advertising changed their perceived was 15\%. 16\% of the respondents disagreed with the assertion that advertising changed their perception on brand quality of auction floors.

Figure 1: Impact of advertising on consumer awareness

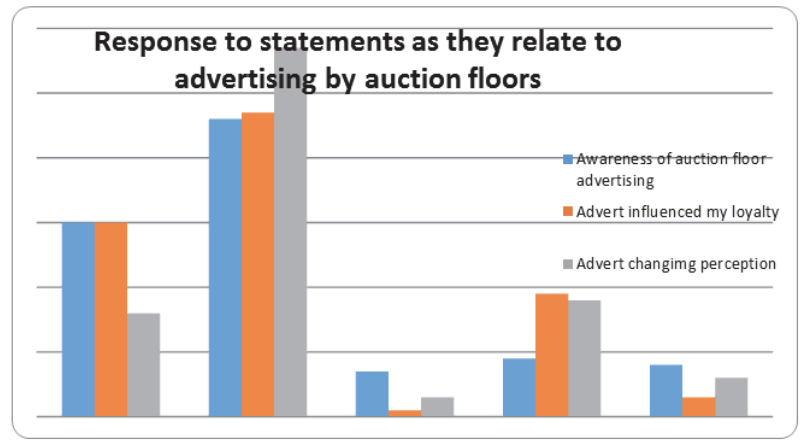

Table 1a : Effect of advertising on brand quality

\section{Advertising and Brand Quality}

\begin{tabular}{|c|c|c|c|c|}
\hline Model & $\mathrm{R}$ & $\mathrm{R}$ Square & Adjusted R Square & Std. Error of the Estimate \\
\hline 1 & $.885^{\mathrm{a}}$ & .783 & .758 & .55942 \\
\hline
\end{tabular}

a. Predictors: (Constant), Attitude, Advert Mode, Number of floors, Input assistance, Customer service, Sources of information, Farmer Type, Competitive price, Floor reputation ,Loyalty

b. Dependent Variable: Brand Quality /Perception

Table 1b: ANOVA for effect of advertising on brand quality

\begin{tabular}{|c|c|c|c|c|c|}
\hline Model & Sum of Squares & Df & Mean Square & $\mathrm{F}$ & Sig. \\
\hline Regression & 100.338 & 10 & 10.034 & 32.062 & $.000^{2}$ \\
\hline Residual & 27.852 & 89 & .313 & & \\
\hline Total & 128.190 & 99 & & & \\
\hline
\end{tabular}

A linear regression analysis was performed to predict brand quality as a function of the type of farmer, source of information, competitive average pricing, loyalty, input assistance, service delivery, number of floors, advert mode, customer service, floor reputation and attitude. There was a strong relationship between brand quality and the independent variables as depicted by the regression coefficient of 0.885 and the model fit is perfect at $78.3 \%$ (Table 1a) indicating that $78.3 \%$ of the variation in brand quality is influenced by the predictor variables. From the ANOVA Table $1 \mathrm{~b}$, a good fit was established between advertising and brand equity with $p=0.001$ which is less than the significance level of 0.05 .

\section{Discussions}

Based on the results of this research, it has been revealed that advertising increases brand awareness as confirmed by 
92\% of the farmers who became aware of auction floors through radio, TV and newspaper advertisements. We therefore conclude that advertisement creates awareness and brand visibility increases with the use of advertisements. The farmers agreed that they get advertisement information through the radio mostly followed by mobile phones and TVs. These results are supported by the views of De Ros (2008) who noted that in order to help check whether or not advertising budgets are earning the best return on investment, it is important to know how effectively advertisement capture and maintain audience attention and engage viewers.

An assessment of how brand loyalty can be created through advertising was one of the research's objective. Interestingly, results indicated that most of the farmers (65\%) have sold to one floor and have not switched floors. Basing on the findings the researcher concluded that radio, newspaper and mobile phone advertisements helped auction floors to get attached to their clients and those clients became loyal to the auction floors they see being advertised. The results are in conformity with Oliver (1999), who noted that loyalty is a deeply held commitment to rebuy a preferred product/service consistently in future thereby causing repetitive same brand purchasing, despite situational influences and marketing efforts having the potential to cause switching behaviour. However, despite the farmers becoming associated with auction floors, the study shows that not much is being done by auction floor managers to lure and build brand association through advertising. Results showed that floor reputation and service delivery at auction floors affect brand association. This is in compliance with observations from Pitta \& Katsanis, (1995) and Lassar, (1995) who concluded that consumers link the performance of the functional attributes to the brand If a brand does not perform the functions for which designed, the brand will has low level of brand equity (Pitta \& Katsanis, 1995 and Lassar, 1995).

The major contribution of the paper is the extension of the role of advertising which has traditionally been limited to creation of awareness to that of building brand equity. It was thus concluded from the findings that advertising role can be extended further to include its use in the building of brand equity.

\section{Conclusions}

In light of the above, the study examined the effects of advertising on brand awareness, brand loyalty, brand association and the perceived quality on brands. The study pointed out advertising creates brand awareness. It also came out of the study that advertising builds repetitive and cognitive loyalty. The research concludes that auction floors should use radio, TV and newspaper to reach their farmers in all tobacco grown provinces and this will enable them to build their brand through these media. Further, we conclude that that auction floor management should invest in marketing and branding in order to increase brand awareness, brand visibility, association and perceived quality. Future research should build on our current research to assess the role of advertising and creating brand association.

\section{References}

Aaker, D., and Keller, K., (1990). Consumer Evaluations of Brand Extensions. Journal of Marketing, 54, 27-40.

Aaker, D., (1993). Are brand equity investments really worthwhile? Free Press, New York.

Aaker, D. A., and Biel, A., (1991). Brand Equity and Advertising; Advertising's Role in Building Strong Brands, Erlbaum, Hillsdale, NJ.

Aaker, D., (1996). Building Strong Brands, Free Press, New York, NY, 150.

Archibald R.B and Haulman, C.A, (1983). Price, Advertising, and Published Quality Ratings. Journal of Consumer Research, 9, 347356.

Balasubramanian, S., Peterson, R. A., and Järvenpää S. L., (2002). Exploring the Implications of M-Commerce for Markets and Marketing, Journal of Academy of Marketing Science 30(4), 348-361.

Baldinger, A.L., and Robinson, J., (1996). Brand loyalty: The link between attitude and behaviour. Journal of Advertising Research, 36(6), 22-34.

Belch, G.E. and Belch, M.A. (2003), Advertising and Promotion: An Integrated Marketing Communications Perspective, New York: McGraw-Hill//rwin.

Bendixen, M.T., (1993). Advertising effects and effectiveness, European Journal of marketing, 27(10) 19-23.

Blattberg, R.C., and Deighton, J., (1996). Manage marketing by the customer equity test, Harvard Business Review, 74(4), $136-144$.

Chen, I.J. (2001). Planning for ERP systems: analysis and future trend, Business Process. Management Journal, 7, (5), $374-86$.

Cobb-Walgren, C.J., Ruble, C.A., and Donthu, N., (1995) "Brand Equity, Brand Preference, and Purchase Intent" Journal of Advertising, 24, 3, 25-40.

Crimmins, J.C., (1992). Better measurement and management of brand value, Journal of Advertising Research, 32, 11-19.

De Chernatony, L., and McWilliam, G., (1989). Clarifying how marketers interpret brands. Journal of Marketing Management, 9 (2), 17388.

De Ros M., (2008). A Content Analysis of Television Ads: Does Current Practice Maximize Cognitive Processing? Indiana University Field, (2013), Small Business Marketing, Start-up Nation LLC. 
Fazio, R., and Powell, D., (1992). How do attitudes guide behaviour? Journal of Consumer Research, 10, 135-146.

Fill, C., (2006). Simply Marketing Communications. Prentice Hall .Pearson Education Limited.

Fletcher, K., and Wheeler, C., and Wright, J., (1990). The Role and Status of UK Database Marketing, Quarterly Review of Marketing, 16 (1), 7-13.

Geoff, L., and Lester, M., (2011). Essentials of Marketing Management. Routledge, Abingdon.

Gonzalez, M. E., and Comesan, L.R., and Brea, J.A.F., (2007).Assessing tourist behavioural intentions through perceived service quality and customer satisfaction. Journal of Business Research, 60(2), 153-160.

Grewal, D. and Levy, M., (2010), Marketing, 2nd Edition, McGraw-Hill, Irwin.

Hankinson, G., and Cowking, P., (1993). Branding in Action, McGraw-Hill, and Maidenhead.

Hansotia B.J., and Wang, P., (1997). Analytical Challenges in Customer Acquisition, Journal of Direct Marketing, 11 (2), 7-19.

Hauser J, R., and Wernerfelt, B., (1990). An evaluation cost model of consideration sets, Journal of Consumer Research, 16, 393-408.

Jefkins, F., and Yadin, D., (2000). Advertising, 4th Edition, Pearson Education Limited.

Keller, K. L, (1993). Conceptualizing, Measuring, and Managing Customer-Based Brand Equity, Journal of Marketing, 57, 1-22.

Keller, K., and Aaker, D., (1992). The effects of sequential introduction of brand extensions, Journal of Marketing research, 25 (1), $35-50$.

Keller K. L., and Lehmann R., (2008). Structure of Survey-Based Brand Metrics, Journal of International Marketing, 16(4), 29-56

Keller, K. L, (2003). Strategic Brand Management: Building, Measuring, and Managing Brand Equity. 2nd Edition. Upper Saddle River New Jersey: Prentice Hall. 2

Kenneth R (1989), Taxes, Financing Decisions, and Firm Value, Journal of Financial Economics, 25, 23-49.

Kerin, R.A., Hartley, S.W., and Rudelius, W., (2011), Marketing. 10th Edition, McGraw-Hill, Irwin.

Kim, K.H., Kim, K.S., Kim, D.U., Kim, J.H., and Kang, S.H., (2008).Brand equity in hospital marketing, Journal of Business Research, 61, 75-82.

Kotler, P., (1988). Marketing Management: Analysis, Planning, Implementation and Control, $6^{\text {th }}$ edition, Englewood Cliffs, NJ: PrenticeHall.

Kotler, P. and Armstrong, G., (2008). Principles of Marketing, Global and Southern African Perspectives 12th Edition, Pearson, Prentice Hall, South Africa.

Krishnan, H.S. and Chakravarti, D., (1990). "Humour in Advertising: testing Effects on Brand Name and Message Claim Memory " in 1990 AMA, Educator's Conference Proceedings.

Laurent, G., and Kapferer, J.N., (1985). Measuring Consumer Involvement Profiles. Journal of Marketing Research, 22, 41-53.

Leppäniemi, M., Sinisalo, J., and Karjaluoto, H., (2006). A Review of Mobile Marketing Research, International Journal of Mobile Marketing, 1(1), 30-40.

Lindsay, R, M., and Ehrenberg, A, S., (1993). The Design of Replicated Studies, The American Statistician, 47(3), 217-228.

Masterman, G., and Emma, H. W., (2005), Innovative Marketing Communications. Elsevier Butterworth-Heinemann, Oxford. United Kingdom.

Mobile Marketing Association (2006). MMA Annual Mobile Marketing Guide: Recognizing Leadership \& Innovation," http://mmaglobal.com/modules/wfsection/article.php?articleid=685

Nelson, S, and Winter G (1974); Survey Research on R\&D Appropriability and Technological Opportunity, The Bell Journal of Economics, 429-446.

O'Guinn, T.C, Allen C.T., and Semenik R. J., (2009). Advertising and Integrated Brand Promotion. 5th Edition, Mason, South-Western Cengage Learning. USA.

O'Leary, C., and Rao, S., and Perry, C., (2004). Improving customer relationship management through database/internet marketing: a theory-building action research project, European Journal of Marketing, 38, (3/4), 338-54.

Patricia, S., and Adam, D., (2007). The Case for Print Media Advertising in the Internet Age, Printing Industry Center at Ritpatrick.

Patrick, D. P., Maggie, G., and Van den, B. (2010). Marketing Communications Prentice Hall, Pearson. Education Limited.

Petit, C., Dubois, C., Harand, A., and Quazzotti, S., (2011). A new, innovative and marketable IP diagnosis to evaluate, qualify and find insights for the development of SMEs IP practices and use, based on the AIDA approach, World Patent Information, 33, 42-50.

Pitta, D.A., and Katsanis, L.P., (1995).Understanding brand equity for successful brand extension, Journal of Consumer Marking, 12(4), 51-64.

Roberts, J., (1986). Relying on the information of interested parties, Rand Journal of Economics, 17: 18-32.

Shimp, T.A., (2008). Advertising, promotion, and other aspects of integrated marketing communications, Mason, Ohio: South-Western Cengage Learning.

Simon, C, J., and Sullivan, M.W., (1993). The measurement and determinants of brand equity: A financial approach, Marketing Science, $12,28-52$.

Smith, R.E., and Swinyard W.R., (1983). Attitude and behaviour consistency: the impact of product trial versus advertising, Journal of Marketing Research, 6, 12-19.

Srivastava, R., and Shocker, A.D., (1991).Brand Equity: A Perspective on its Meaning and Measurement. Working Paper Series, Report Number 91-124. Cambridge, MA: Marketing Science Institute.

Stewart, D.W., and Kamins, M.A., (1993).Secondary Research. Information Sources and Methods, Newbury Park, CA: Sage.

Taylor, S. A., and Goodwin, S., (2005). An Exploratory Investigation into the Question of Direct Selling via the Internet in Industrial Equipment Markets. Journal of Business To Business Marketing, 12 (2), 39-72.

Tsai, C.H., and Tsai, M., (2006). The impact of message framing and involvement on advertising effectiveness: The topic of oral hygiene 
as an example. Journal of American Academy of Business, 8(2), 222-226.

Wegner, T., (1993). Applied Business Statistics: Methods and Applications. Creda Press, Republic of South Africa.

Yoo, B., and Donthu, N., (1997). Developing and Validating a Consumer-Based Overall Brand Equity Scale for Americans and Koreans: An Extension of Aaker's and Keller's Conceptualizations. LAMA Summer Educators Conference, Chicago IL.

Zeithaml, V. A., (1988), Consumer Perceptions of Price, Quality, and Value: A Means end Model and Synthesis of Evidence. Journal of Marketing, 52, 2-22. 